\title{
Proceeding
}

Supplementary Issue: Summer Conferences of Sports Science. Costa Blanca Sports Science Events, 20-21 September 2019.

Alicante, Spain.

\section{Effectiveness and influence of some technical fundamentals on the game's quality in football}

\author{
TIZIANA D'ISANTO \\ MIUR Campania, Italy
}

\begin{abstract}
Fundamental aspects that led some team of soccer to become the best in Europe will be analysed. The teams football leagues of the main Italian, Spanish, English and German national teams, have a different attack and characteristics of game. The objective of the study is to analyse the common elements of the shots on target, the recovered balls, the possession of the ball and the number of completed passes on four European soccer teams. The method is experimental and based on the analysis of Anova and Post hoc test of the data. We hypothesize that the results should show a disparity in the four different categories of data between the teams. Consequently, the results of this study could be useful to optimize the soccer training load and the tactical training. Keywords: Match analysis; Recovered balls; Successful passes; Throws on goal; Possession ball.

\section{Cite this article as:}

D'Isanto, T. (2019). Effectiveness and influence of some technical fundamentals on the game's quality in football. Journal of Human Sport and Exercise, 14(5proc), S2026-S2030. doi:https://doi.org/10.14198/ihse.2019.14.Proc5.24
\end{abstract}

Corresponding author. MIUR Campania, Italy. http://orcid.org/0000-0001-7151-7486

E-mail: tizidisanto@libero.it

Supplementary Issue: Summer Conferences of Sports Science. Costa Blanca Sports Science Events, 20-21 September 2019. Alicante, Spain.

JOURNAL OF HUMAN SPORT \& EXERCISE ISSN 1988-5202

(c) Faculty of Education. University of Alicante doi:10.14198/jhse.2019.14.Proc5.24 


\section{INTRODUCTION}

Soccer is a high-situational sport with a high agonistic engagement (Gaetano \& Rago, 2014), where the precision and the power are the most important aspects for achieve a winning (Silvestri et al, 2019a). Football is a situation sport, because it has movements without a repeatability pattern (Raiola, 2019abc, 2017, 2013, 2011ab); in fact, it is a sport team in which the performance depends also from the presence of one or more opponents (Giordano et al, 2019). In Italy, as in Europe, has already been the case for years abroad, terms such as match analysis, video analysis and performance analysis (Altavilla, 2019, Altavilla, Raiola, 2018, Altavilla et al., 2017). Match analysis and video analysis are the performance analysis tool to aim for providing qualitative and quantitative information on the performance of individual players and of the team (D'Isanto et al., 2019). In Italy, as in Europe, in recent years, terms such as match analysis, video analysis and performance analysis (Raiola et al., 2013) are increasingly part of the football vocabulary. Match analysis and video analysis are the performance analysis tool to aim for providing qualitative and quantitative information on the performance of individual players and of the team (Izzo et al, 2018). The use of match analysis by the coaches and athletic trainers has certainly widened the definition of the football performance model (Ruosi, 2007). It is important to consider that the physical profile of football players is very variable, having implications for the interpretation of the match. But it is important also to know the influence that the successful passes, throws on goal, the recovered ball and possession ball by a team to know type of game's quality (Silvestri et al, 2019b). The research hypothesis is to verify if there is a homogeneity among the teams taken into consideration, in the number of successful passes, the recovered balls, the throws on goal and the possession of the ball, and how much these variables influence the game's quality. The teams surveyed participated in the Champions League last year, specifically they are: Barcelona, Borussia Dortmund, Juventus and Liverpool.

\section{METHODS}

The method is experimental and based on the analysis of Anova and Post hoc test of the data obtained from the InStat database. The study was conducted on the analysis of twenty matches of four European soccer teams: Barcelona, Borussia Dortmund, Juventus and Liverpool. The research hypothesis consists in identifying if there is a homogeneity in the possession of the ball, the throws on goal, the recovered balls and the successful passes by the teams being researched.

\section{Statistical analysis}

The statistical analysis is based on the Anova and Post hoc test calculation. The data sample is represented by the matches played by the four teams examined. The data for the statistical analysis, and therefore for the calculation of the averages, of the percentages and of the standard deviations, were extrapolated from the videos of the matches examined and compared with the data provided by the InStat site.

\section{RESULTS}

Table 1. Anova and Post hoc test - There no difference on successful passes.

\begin{tabular}{lccc}
\hline Teams & $\mathbf{F}$ & $\mathbf{P}$ & Post hoc test \\
\hline 1-Barcelona & 1.340 & 0.268 & - \\
2-Borussia Dortmund & & & \\
3-Juventus & & & \\
4-Liverpool & & & \\
\hline
\end{tabular}


Table 2. Anova and Post hoc test - There is difference on possession ball.

\begin{tabular}{lccc}
\hline Teams & $\mathbf{F}$ & $\mathbf{P}$ & Post hoc test \\
\hline 1-Barcelona & 52.573 & 0.000 & V2>V1. V3 and V4 \\
2-Borussia Dortmund & & & \\
3-Juventus & & & \\
4-Liverpool & & & \\
\hline
\end{tabular}

Significance level on $p<0.05$.

Table 3. Anova and Post hoc test - There is difference on throws on goal.

\begin{tabular}{lccc}
\hline Teams & $\mathbf{F}$ & $\mathbf{P}$ & Post hoc test \\
\hline 1-Barcelona & 2.863 & 0.042 & V2>V1. V3 and V4 \\
2-Borussia Dortmund & & & \\
3-Juventus & & & \\
4-Liverpool & & & \\
\hline
\end{tabular}

Significance level on $p<0.05$.

Table 4. Anova and Post hoc test - There is difference on recovered balls.

\begin{tabular}{lccc}
\hline Teams & $\mathbf{F}$ & $\mathbf{P}$ & Post hoc test \\
\hline 1-Barcelona & 52.573 & 0.000 & V2>V1. V3 and V4 \\
2-Borussia Dortmund & & & \\
3-Juventus & & \\
4-Liverpool & & \\
\hline & Significance level on $p<0.05$. &
\end{tabular}

In the tables 1, 2, 3 and 4 is shown the results on the four variables following: possession of the ball, throws on goal, recovered balls and successful passes. The hypothesis is not been verificated, in fact, there is significant difference between the four teams, in particular the team (V2 - Borussia Dortmund) results significantly different on three technical variables compared to the other teams, as the post hoc test shows.

\section{DISCUSSION}

The four teams result not homogeneous from the Anova tests. There is no significant difference between the four teams in successful passes, a value well above the level set with $p<0.05$ (Table $n .1, p=0.268$ ). Instead, there are significant differences between the four teams, as far as the other technical variables are concerned: in the possession of the ball (Table n.2, $p=0.00$ ), in the shots taken (Table $n .3, p=0.042$ ) and in the recoveries ball (Table $n .4, p=0.00$ ). In particular, through the post hoc test it was possible to establish which team showed a greater significant difference, both for the possession of the ball, for the recovered balls, and for shots made on goal and in the quality of the game (V2 = Borussia Dortmund).

\section{CONCLUSION}

The research hypothesis was not confirmed by the analysed data. The four groups are not homogeneous, on the contrary Borussia Dortmund shows clear differences from the other teams and also in the quality of the game (like game aesthetics and practicality). From the study of the emerged data and from the video analysis of the games taken into consideration, it can be stated that the game of Borussia Dortmund is based on the quality and quantity of the ball possession and then reaches the goal thanks to a series of filtering passes. In anticipation of further future studies these data could be correlated with short passages, long 
passages, number of successful dribbles, with goals scored, with the number of crosses from right and left. In such a way as to have a good view of the dynamics of the construction and the finalization of the game of the examined teams.

\section{REFERENCES}

Altavilla, G. (2019) Monitoring training to adequate the teaching method in training: an interpretative concepts, Journal of Physical Education and Sport vol.19 (Supplement issue 5), pp. 1763-1766.

Altavilla, G., Gaetano, R. (2018)Physiological effects of warm-up and problems related to team sports, Sport Science, 11, pp. 83-88.

Altavilla, G., Riela, L., Di Tore, A.P., Raiola, G. (2017) The physical effort required from professional football players in different playing positions. Journal of Physical Education and Sport, 17 (3): 20072012.

Gaetano, R., Rago, V. (2014). Preliminary study on effects of hiit-high intensity intermittent training in youth soccer players, Journal of Physical Education and Sport, 14 (2): 148-150.

D'Isanto, T., D'Elia, F., Raiola, G., Altavilla, G. (2019). Assessment of sport performance: Theoretical aspects and practical indications, Sport Mont, 17 (1), 79-82.

Raiola, G., (2019a) Complex study for an epistemology of Exercise and sport sciences: a) key concepts of both ERC subpanels and CUN keywords; b) Physical training and sport methodology sciences academic disciplines in pedagogy recruitment sector and biomedical one: a correlationships study Journal of Physical Education and Sport vol.19(Supplement issue 5), pp. 1748 - 1754.

Raiola, G. (2019b) Survey on exercise and sport sciences in Italy Journal of Human Sport and Exercise, 14 (Proc4), pp. S1163-S1168. https://doi.org/10.14198/jhse.2019.14.Proc4.81

Raiola, G. (2019c) Comparison of exercise and sport sciences epistemology between European research council structure panel and Italian academic system Sport Science, 12, pp. 112-120.

Raiola, G. (2017) Motor learning and teaching method, Journal of Physical Education and Sport, 17, art. no. 236, pp. 2239-2243.

Raiola, G., Parisi, F., Giugno, Y., Di Tore, P.A. (2013) Video analysis applied to volleyball didactics to improve sport skills, Journal of Human Sport and Exercise, 8 (2 SUPPL), 307-313. https://doi.org/10.4100/jhse.2012.8.proc2.33

Raiola, G. (2013) Body knowledge and motor skills, Knowledge Cultures, 1 (6), pp. 64-72.

Raiola, G. (2011a)A study on Italian primary school rules: Neurophysiological and didactics aspects on physical education and sport, Journal of Physical Education and Sport, 11 (2), pp. 43-48.

Raiola, G. (2011b) Study between neurophysiological aspects and regulation documents on preschool in Italy, Journal of Physical Education and Sport, 11 (1), pp. 42-47.

Ruosi S., "La matchanalysis, un nuovo supporto per la metodologia dell'allenamento nel calcio"; Tesi di abilitazione a preparatore atletico di calcio, Coverciano (FI), Settore Tecnico FIGC, 2007.

Izzo, R., Sopranzetti, S., Hosseini Varde'I, C., Molitierno, G. (2018) Video tracking for the detection of external load to establish proper parameters in elite soccer players during high intensity training, Journal of Physical Education and Sport, 18, 1199-1202.

Giordano, L., Federici, A., Valentini, M., D'elia, F. (2019) Dribbling in football: Confronting learning theories, Journal of Human Sport and Exercise, 14 (Proc2), S228-S232. https://doi.org/10.14198/ihse.2019.14.proc2.10

Silvestri, R., D'Isanto, T., Izzo, R., Di Domenico, F. (2019b). The winning shares in the major football leagues, Journal of Human Sport \& Exercise, 14(4):631-637. https://doi.org/10.14198/ihse.2019.14.proc4.22 


\section{(c) (1) (9)}

This work is licensed under a Attribution-NonCommercial-NoDerivatives 4.0 International (CC BY-NC-ND 4.0). 